\title{
Jarosław Włodarczyk
}

ORCID: 0000-0002-7655-1138

Press Club Polska

\section{Macchiato do ostatniej kropki}

https://doi.org/10.19195/0867-7441.26.30

Recenzja: Jacek Dąbała, Medialne fenomeny i paradoksy, Universitas, Kraków 2020, ss. 257.

Słowa kluczowe: media, dziennikarstwo, dziennikarstwo jakościowe, aksjologia, myślenie, komunikowanie

Keywords: media, journalism, quality journalism, axiology, thinking, communication

Media są dziś na zakręcie rewolucyjnych zmian i poszukują metod na to, jak $\mathrm{z}$ tego zakrętu wyjść. Dla dziennikarzy i ludzi mediów na całym świecie lektura Medialnych fenomenów i paradoksów może być nieprzyjemnym przejrzeniem się w lustrze i poważną nauką. Dla odbiorców zaś - kluczem do lepszego rozumienia świata. To nie jest książka tylko o mediach, ale o świecie widocznym w mediach. To świat z mediów opowiedziany na nowo.

Jeśliby podejmować próbę syntezy problemów współczesnych mediów, na pierwszy plan wysuwają się spadek zaufania do dziennikarzy, zmniejszające się znaczenie tradycyjnych mediów w ogólnym obiegu informacji, obniżanie się poziomu mediów ${ }^{1}$, a w konsekwencji także destabilizacja podstaw materialnych redakcji. Do tego dochodzą: wymuszana przez odbiorców potrzeba ścigania się redakcji z czasem oraz trudność w zachowaniu niezależności dziennikarskiej, spowodowana chociażby przez naciski polityczne i biznesowe. Katalog tych zjawisk zająłby niejedną książkę.

Na problemy mediów nakładają się negatywne zjawiska społeczne zagrażające demokracji i dokonywaniu przemyślanych wyborów — od stylu życia, decyzji zakupowych czy wpływania na środowisko aż po głosowania w demokracjach. Wielu badaczy upatruje źródeł tych problemów w Internecie, w szczególności w serwisach społecznościowych ${ }^{2}$, które stymulują — z nieznaną w historii szyb-

${ }^{1}$ Spadek poziomu mediów wymagałby odrębnego omówienia. Zainteresowanym czytelnikom polecam przyjrzenie się zjawiskom opisywanym szeroko w badaniach medioznawczych — są to między innymi: spłycenie przekazu, agenda-setting, tabloidyzacja, fragmentacja, dramatyzacja i celebryzacja polityków.

2 Celowo posługuję się określeniem „serwisy społecznościowe”, a nie „media społecznościowe”. To drugie, choć powszechne, wydaje się błędne w odniesieniu do serwisów niewytwarzających treści, a tylko je agregujących. 
kością i skutecznością — atomizację społeczeństw i polaryzację postaw. Sprzyja to szerzeniu się między innymi dezinformacji, wyrastaniu nowych autorytetów niemających ani wiedzy, ani doświadczenia oraz wzrastaniu popularności teorii spiskowych. Jakby tego było mało, politycy, szczególnie populiści, ale nie tylko, dostrzegli wielką szansę w istnieniu „mętnej przestrzeni informacyjnej”, w dezorientacji obywateli pozbawionych samodzielnego myślenia i słabo wykształconych. I z całą premedytacją wykorzystują te okoliczności do rośnięcia w siłę oraz atakowania czy nawet eliminowania niezależnych dziennikarzy i wolnych mediów. Dziennikarze są bowiem pierwszą linią obrony przed rozprzestrzenianiem się dezinformacji. Wolne media są także barierą autorytarnych zapędów polityków, pokazując, co się dzieje z naszymi prawami i innymi wolnościami.

Mechanizmy te doskonale rozumieją dziennikarze czy szerzej — ludzie mediów. Postulują zatem konieczność odbudowania zaufania do mediów, stworzenie stabilnych warunków do działania niezależnych mediów jako strażników demokracji oraz powrót do jakościowego dziennikarstwa. Pojawiają się liczne próby ratowania mediów i odwrócenia negatywnego trendu: Unia Europejska chce, aby serwisy społecznościowe (głównie Facebook i Google), pasożytujące na dziennikarstwie, zaczęły płacić za wykorzystywane treści, czemu dała wyraz w uchwalonej dyrektywie o prawach autorskich w Internecie; w szkołach w wielu krajach zostaje wprowadzony przedmiot edukacja medialna, który ma pomóc przedzierać się przez informacyjną dżunglę; główne agencje prasowe, jak choćby Agence France Press, Associated Press, Reuters, DPA, i wielkie redakcje, jak BBC, „Washington Post” czy „New York Times”, powołały w ramach swoich struktur osobne redakcje fact-checkingowe, weryfikujące prawdziwość informacji krążących w sieci czy wypowiadanych przez osoby publiczne i eliminujące fałszywki (fake news); powstają zupełnie nowe modele funkcjonowania mediów finansowanych z darowizn odbiorców (na przykład OKO.press) ${ }^{3}$; w Danii zaś rodzi się manifest konstruktywnego dziennikarstwa (constuctive journalism). To tylko kilka przykładów spośród wielu nowych inicjatyw, pomysłów, rozwiązań budzących ogromne nadzieje dziennikarzy i medioznawców, bo wszyscy, mając świadomość misji mediów, chcą ratować demokratyczne społeczeństwa. Społeczeństwa zaś, aby przetrwać, potrzebują właśnie mediów jako wiarygodnych źródeł informacji oraz narzędzi poszerzających obszar uwspólnionej wiedzy o otaczającym świecie. Trwałe efekty tych działań wymagają jednak czasu, którego raczej już nie ma.

$\mathrm{Na}$ te nadzieje oraz potrzeby czasów w znacznym stopniu odpowiada książka profesora Jacka Dąbały Medialne fenomeny i paradoksy. Autor pokazuje, apeluje, woła o jakość w mediach, o oczekiwanie przez odbiorców tej jakości, o lepsze rozumienie mediów, o wiarygodne i mądre media. Jest to w istocie postulat krytycznego myślenia. I choć nie jest on wyrażony wprost, wydaje się tak ważki

${ }^{3}$ Nowy model finansowania społecznościowego zapewnia co prawda stabilizację, ale sam generuje potencjalnie kolejny problem — pułapkę dziennikarstwa tożsamościowego schlebiającego przekonaniom darczyńców, a nie w służbie obiektywizmu i prawdy. 
i słuszny, że właśnie krytyczne myślenie może chronić odbiorców przed manipulacjami, a dziennikarzom ułatwia tworzenie jakościowych treści.

Lektura tej książki jest jednak ryzykowna. Zachęcająca forma miniesejów i wartki styl dają ułudę przyjemnej i łatwej lektury. Jednak po przeczytaniu kilku stron nawet mało uważny czytelnik dostrzeże, że to caffè macchiato, że pod frywolną i delikatną pianką jest bardzo mocna kawa, która budzi. Budzi do myślenia. Autor zdecydował się na wybór formy krótkiego eseju naukowego, ponieważ — jak sam pisze we wstępie — „współczesny świat jest tak dynamiczny i przeładowany informacjami, iż warto go pokazać - dla lepszego nawiązania kontaktu i zrozumienia - w uniwersalnym skrócie. Stąd wzięła się perspektywa fenomenów i paradoksów" (s. 17).

Całość napisana jest minimalistycznie, językiem prostym i zrozumiałym. Zbudowana jako zbiór 200 tekstów, po mniej więcej 2000 znaków każdy. Znając dorobek i warsztat Jacka Dąbały nie tylko jako naukowca, ale również pisarza i scenarzysty, należy z uznaniem patrzeć na tę powściągliwość formy i stylu. Autor wymaga przy tym od czytelnika jedynie przeciętnych kompetencji językowych i kulturowych. Rzuca za to wyzwanie jego uwadze, inteligencji i rozumieniu.

Nawet Umberto Eco, mistrz krótkich form prezentacji wyników przemyśleń i badań nad mediami i komunikowaniem, nie zachowywał takiej dyscypliny struktury i długości tekstów jak profesor Dąbała. W wypadku tego drugiego to nie tylko staranność w konsekwentnym trzymaniu się przyjętej reguły, ale $\mathrm{i}$ - a może przede wszystkim - wprowadzenie jednolitego rytmu, marszu intelektu, który zaprasza czytelnika do dotrzymywania kroku, przyjęcia stałego sposobu, stałej metody strukturalnego myślenia, w zaproponowanej kolejności: teza, definiowanie, diagnozowanie i analizowanie, a wreszcie wnioskowanie, synteza i zwykle propozycja rozwiązania. Wybór tej skondensowanej formy poszczególnych tekstów pozwala czytelnikowi nie marnować czasu na czytanie niepotrzebnych, a jakże częstych w wielu tekstach naukowych, wypełniaczy, mających na celu głównie udowodnienie wszechstronności autora i tworzenie wrażenia biegłości w danej materii.

Dla co najmniej dwóch grup czytelników lektura tej książki może być dokuczliwa, momentami irytująca, a jednocześnie niezwykle pożyteczna. Pierwsza z nich to dziennikarze i redaktorzy — irytująca, bo nikt nie lubi wytykania błędów czy wskazywania bezmyślności, lenistwa i odchodzenia od zawodowej deontologii. Druga grupa to czytelnicy o konserwatywnych poglądach — tu lektura może okazać się tym ciekawsza, bardziej wartościowa, im bardziej czytelnik może się zderzyć, przejrzeć w innym sposobie patrzenia, myślenia. I tym trudniejsza, że nie można Dąbale odmówić żelaznej logiki i rozsądku.

Żeby dodatkowo uzmysłowić, jak starannie, przemyślanie, ale i zabawnie napisana jest ta książka, polecam przy lekturze zwrócić uwagę na korelację tytułu czy tematu z ostatnim wyrazem lub wyrażeniem danego eseju. To właśnie wirtuozeria i zabawa słowem, która uważnemu czytelnikowi daje radość i poczucie obcowania z czymś i kimś mądrym, i jest jednocześnie kolejną prowokacją do myślenia. 
Oszczędność formy jest zrównoważona mnogością poruszonych tematów i zagadnień. Na kolejnych stronach pojawiają się nauka, polityka, historia, medycyna, media, technologie, obyczaje, prawo, religia, wiara, emocje, intelekt i głupota. Podróżujemy przez tematy, lecz także przez miejsca. Jesteśmy w Rosji, w Chinach, w Stanach Zjednoczonych, w Niemczech czy wreszcie w Polsce. Wspólnie obserwujemy całe kontynenty i małe wspólnoty. Ponadto poruszane tematy i ich analizy są tak uniwersalne, że szybko się nie zdezaktualizują, a można nawet zaryzykować tezę, że wiele z nich będzie mieć charakter ponadczasowy. Jest to zatem lektura globalna i uniwersalna, która powinna wyjść poza wąski krąg języka polskiego, zostać przetłumaczona i polecana jako istotna treść dla dziennikarzy, polityków, studentów, wszystkich ludzi związanych z mediami, komunikujących się w codziennym życiu, a nawet szerzej — dla nas wszystkich, czyli odbiorców mediów.

Czy Dąbała jest w swoich tekstach obiektywny? Nie, nie jest. To subiektywne spojrzenie na wszystkie poruszone 200 tematów przez pryzmat poglądów prodemokratycznych (co autor sam podkreśla w książce, choć także zauważa niedoskonałości demokracji) i wolności — wolności rozumianej najszerzej: wolności naukowej i wolności słowa.

Można nawet odnieść wrażenie, że autor sam sobie zaprzecza. Postuluje bowiem oddzielanie faktów od opinii, a jednocześnie decyduje się na formę esejów, w których fakty i opinie wzajemnie się przenikają. Ale to wrażenie zaprzeczania samemu sobie przez Dąbałę jest zwodnicze. Jego książka, choć co chwilę odnosi się do dziennikarstwa i można poczuć czasem publicystyczne zacięcie, to jednak sama pracą dziennikarską nie jest. Nie podlega ona zatem postulowanym prawidłom. Medialne fenomeny $i$ paradoksy to naukowa, precyzyjna analiza zjawisk w mediach i opisywanych przez media, to spojrzenie na te problemy z wielu perspektyw - szeroko, specyficznie, a czasem i z metapoziomu.

Czy Dąbała daje w tych tekstach odpowiedzi? Na pewno stawia ważne pytania, kwestionuje nasz sposób widzenia świata i jego przedstawienia w mediach. Jednak postawione pytania często pozostawia bez odpowiedzi. Pozornie, albowiem odpowiedzią jest metoda. Innymi słowy brakuje dziś w mediach myślenia i jakości. Ta książka stara się do tego odnosić - nie odpowiada na wszystkie pytania, ale pokazuje sposób analizy, myślenia, wnioskowania. Uczy, jak problemom mediów i świata stawiać czoła.

Dąbała zaproponowaną metodą analizy, szerokością spojrzenia oraz wnikliwością rozumowania udowadnia, że należy do niezbyt licznego w skali świata grona wyjątkowych naukowców czy szerzej — intelektualistów, którzy są w stanie dostarczyć odbiorcy klucz do lepszego rozumienia świata. W dobie zalewu płytkich opinii głęboka refleksja jest coraz bardziej deficytowa. Praca Dąbały dostarcza w każdym tekście przemyśleń fascynujących, odkrywczych, często zaskakujących, a dla wielu przełomowych. Czasem nawet może ogarniać czytelnika 
zdziwienie, że samodzielnie nie doszedł do tak logicznych, zdawałoby się oczywistych, wniosków.

Jako absolwent studiów dziennikarskich, co prawda ukończonych wiele lat temu, ale jeszcze pamiętający liczne zajęcia ciekawe i ważne, lecz także umiarkowanie mądre, jestem przekonany, że książka Medialne fenomeny i paradok$s y$ jest znakomitym materiałem do prowadzenia innowacyjnych warsztatów dla studentów dziennikarstwa. Wyobrażam sobie angażujące zajęcia z początkowym omówieniem wybranego eseju, a później dyskusją wokół jego tematu: jak jest on przedstawiany w mediach, jak media ten temat kształtują, jak wpływają na obraz wśród odbiorców, jak powinien relacjonować to etyczny i profesjonalny dziennikarz... Pytania można mnożyć. Sprowadza się to do najważniejszego — studenci mieliby możliwość obcowania z poważną, realną i użyteczną refleksją nad przyszłym zawodem. A ta, szczególnie ostatnio, wydaje się niezbędna.

Pomysł ten można także zastosować w gronie profesjonalnych dziennikarzy: od szefów redakcji, przez redaktorów, po reporterów. Taka analiza może rozwijać, doskonalić myślenie dziennikarskie. Nie jest to łatwe, bo nazbyt często redaktorzy naczelni czy „gwiazdy” dziennikarstwa są przekonani o swojej wyższości i zatracają zarówno dziennikarski instynkt, jak i gotowość do ciągłego uczenia się. Na szczęście w wielu dobrych redakcjach i ważnych mediach są grupy znakomitych dziennikarzy, którzy tworzą doskonałe media właśnie dlatego, że potrafią każdego dnia słuchać i krytycznie myśleć. I dla nich takie ćwiczenie może być bardzo cenne.

Podsumowując, podkreślmy raz jeszcze, że społeczeństwa, demokracje, media i dziennikarstwo przechodzą dziś transformację niespotykaną w historii. Kluczowym elementem tych zmian jest informacja, dostęp do niej oraz możliwości i umiejętności jej przetwarzania. Bez rozumienia tego procesu, bez umiejętności selekcji informacji i bez krytycznej analizy poszczególni ludzie i całe społeczeństwa stają się bezbronne wobec głupoty, wojen informacyjnych, dezinformacji $\mathrm{i}$ ingerencji w wybory. Wydana w 2020 roku książka profesora Jacka Dąbały $\mathrm{Me}$ dialne fenomeny $i$ paradoksy diagnozuje te problemy i wyzwania oraz wskazuje klucz do medialnego, informacyjnego myślenia. To ważna wiedza dla każdego, kto chce lepiej rozumieć świat, a dla ludzi mediów — lektura obowiązkowa.

\section{Bibliografia}

Bard A., Söderqvist J., Netokracja, przeł. P. Cypryański, Wydawnictwa Akademickie i Profesjonalne, Warszawa 2006.

Bennett L.W., News: The Politics of Illusion, Longman, New York 1988.

Bourdieu P., O telewizji. Panowanie dziennikarstwa, przeł. K. Sztandar-Sztanderska, A. Ziółkowska, Wydawnictwo Naukowe PWN, Warszawa 2011.

Dąbała J., Medialne fenomeny i paradoksy, Universitas, Kraków 2020. 
Dąbała J., Twój umyst pod lupa, wywiad przepr. ks. R. Pastwa, „Gość Lubelski/gosc.pl” 2020, nr 5. Dylemat spoteczny (The Social Dillema), reż. J. Orlowski, USA 2020.

Eco U., Drugie zapiski na pudetku od zapałek 1991-1993, Historia i Sztuka, Poznań 1994.

Eco U., Zapiski na pudetku od zapałek, Historia i Sztuka, Poznań 1993.

The Guardian: The Cambridge Analytica Files, https://www.theguardian.com/news/series/cambrid ge-analytica-files.

Herman E.S., Chomsky N., Manufacturing Consent: The Political Economy of the Mass Media, Pantheon Books, New York 1988.

Hordecki B., Piontek D., Tabloidyzacja czy tabloidyzacje telewizyjnych programów informacyjnych? (Fakty TVN i Wiadomości TVP), „Środkowoeuropejskie Studia Polityczne” 2010, s. 19-33.

Jowett D.G., O’Donnell V., Propaganda and Persuasion, Sage Publications, Los Angeles 2012.

Kepplinger H.M., Mechanizmy skandalizacji w mediach, przeł. A. Kożuch, Wydawnictwo Uniwersytetu Jagiellońskiego, Kraków 2008.

Kiesewetter J., In 20 years, CNN has changed the way we view the news, „Cincinnati Enquirer” 28.05.2000.

Knightley K. Zmuszona do myślenia, wywiad przepr. K. Kwiatkowski, „Gazeta Wyborcza” 2.02. 2008.

Kolczyński M., Mazur M., Michalczyk S., Mediatyzacja kampanii politycznych, Wydawnictwo Uniwersytetu Śląskiego, Katowice 2009.

Kolenda-Zaleska K., W tym maglu nikt nie jest bez winy, „Gazeta Wyborcza” 15.05.2012.

Lewicki G., Włodarczyk J., News wars. Informacja, dziennikarze i media w erze neomediewalnej, [w.] Foresight Społeczny Wrocław 2036/56 - Miasto Przyszłości, red. G. Lewicki, t. 1. Miasta w nowym średniowieczu, Wrocław Biuro Festiwalowe Impart, Wrocław 2016, s. 107-126.

Livingston S., Clarifying the CNN Effect: An Examination of Media Effects According to Type of Military Intervention, Research Paper R-18: President and Fellows of Harvard College, Cambridge 1997.

Maj S., Drzwi percepcji XXI wieku, „Rzeczpospolita” 25.05.2020.

Mazur S., Ewolucja sfery publicznej i mechanizmów zarządzania publicznego w kontekście wytwarzania ,,wiedzy uwspólnionej”, „Rocznik Lubuski” 43, 2017, nr 2, s. 9-24.

Mazzoleni G., Schulz W., Mediatization of Politics: A Challenge for Democracy?, „Political Communication" 16,1999 , s. 247-261.

Miecugow G., Tabloidyzacja odbiorców niszczy media. Największa słabościa telewizji jest widz, wywiad przepr. S. Kucharski, „Gazeta Wyborcza” 22.09.2012.

Oniszczuk Z., Mediatyzacja polityki i polityzacja mediów. Dwa wymiary wzajemnych relacji, „Studia Medioznawcze" 2011, nr 4 (47), s. 11-22.

Seife Ch., Virtual Unreality: Just Because the Internet Told You, How Do You Know It's True?, Penguin Books, London 2015.

Shirky C., Here Comes Everybody: The Power of Organizing Without Organizations, Penguin Group, London 2008.

Silverman C., Regret the Error: How Media Mistakes Pollute the Press and Imperil Free Speech, Sterling Publishing Company, New York 2009.

Sullivan M., Ghosting the News. Local Journalism and the Crisis of American Democracy, Columbia Global Reports, New York 2020.

Szurmiński Ł., Tabloidyzacja mediów. Grzegorzu Miecugow, to nie widzowie, to media posunęły się za daleko, „Gazeta Wyborcza” 26.09.2012. 


\title{
Macchiato to the last dot
}

\author{
Summary
}

Today's societies, democracies, media and journalism are undergoing a transformation hitherto unheard of in history. The key element of these changes is information and access to it, as well as processing possibilities and skills. Without understanding the process, without the ability to select information, and without critical analysis, individuals and entire societies become vulnerable to stupidity, information wars, disinformation and interference with elections.

Politicians, especially populists but not exclusively so, saw a great opportunity in the existence of a "cloudy information space", in the confusion of citizens deprived of their independent thinking and poorly educated. That is why politicians fight with free media and independent journalists, because this is the first line of defence against disinformation and ignorance. Freedom of media is also a barrier to the authoritarian aspirations of politicians, because of its unique attribute - the only freedom showing the state of other freedom and rights.

The book by professor Jacek Dąbała, Media phenomena and paradoxes, published in 2020, diagnoses these problems and challenges and shows the key to media and information thinking. It is written in a minimalistic form of 200 texts, each of about 2000 characters. The short form is balanced by the multitude of topics covered, including science, politics, history, medicine, media, technologies, customs, law, religion, faith, emotions, intellect and stupidity. Dąbała scans issues in Russia, China, the United States, Germany, Poland and many others. The topics and analyses are universal and you can even risk a thesis that many of them will be timeless. It is therefore a global and universal reading which, when translated into other languages, should be recommended as essential content for journalists, politicians, students, and even more broadly - for all of us, that is, media recipients.

The book is a subjective view of all the 200 topics through the prism of pro-democracy views and freedom - freedom understood in the broadest sense, freedom of science and speech.

Dąbała certainly poses important questions, questioning our way of seeing the world and its presentation in the media. However, he often leaves the questions unanswered, apparently because the answer is in the method - analysis, critical thinking and seeking quality.

The book Media phenomena and paradoxes is excellent material for conducting workshops for journalism students. Analysing problems in the book can also improve journalistic thinking. For journalists who have not lost their instincts, humility and willingness to keep going, such an exercise can be very valuable.

This is important knowledge for anyone who wants to better understand the world, and for media people it is a must-read. 